\title{
Triple Negative Breast Cancer, Clinicopathologic Study of Egyptian Patients, NCI Experience
}

\author{
AL-SHIMAA ZAKARIA, M.Sc. ${ }^{\mathbf{1}}$; NAGLAA EL-KINAAI, M.D. ${ }^{\mathbf{1}} \mathbf{2}^{\mathbf{2}}$; IMAN LOAY, M.D. ${ }^{\mathbf{1}}$; \\ HANAN RAMADAN NASSAR, M.D. ${ }^{\mathbf{3}}$; TAREK DARWISH, M.D. ${ }^{\mathbf{3}}$; MERVAT EL-DEFTAR, M.D. ${ }^{\mathbf{1}}$; \\ RASHA MAHMOUD ALLAM, M.D. ${ }^{4}$ and HASAN NABIL, M.D. ${ }^{1}$ \\ The Department of Pathology, National Cancer Institute, Cairo University ${ }^{1}$ and Children's Cancer Hospital, Cairo ${ }^{2}$, \\ The Departments of Medical Oncology ${ }^{3}$ and Biostatistics \& Cancer Epidemiology ${ }^{4}$, National Cancer Institute, \\ Cairo University, Egypt
}

\begin{abstract}
Background: Triple negative breast cancer category is a challenging group of breast cancer. It needs more detailed clinical and pathological studies.

Aim of Study: To study the clinicopathologic characteristics of triple-negative breast cancer of Egyptian patients.

Patients and Methods: A retrospective study was done included 59 women with triple negative breast cancer collected from Pathology Department at NCI, Cairo University, Egypt. Clinical data and pathological data were revised, then followup of the cases with a median follow-up time 40.5 months (range: 8-67).
\end{abstract}

Results: Most cases were equal or below 50 years old post-menopausal, and unilateral. According to pathological characters, majority of cases represented grade $2, \mathrm{~T} 2$, positive lymph nodes, and stage 2 . As regards outcome three cases underwent recurrence, seven cases underwent metastasis, and two cases show metastasis and recurrence. At the end of the study 44 cases were alive, ten died, and five show lost followup. There was a significant relationship found between grade and DFS, as well as OS with grade, stage, occurrence of metastasis and node positivity.

Conclusion: Triple negative breast cancer group were more noticed among age group less than 50 years, with tendency to express high grade, large tumor size, high stage and node positivity, with significant relationship between grade and DFS, as well as OS with grade, stage, occurrence of metastasis and node positivity.

Key Words: TNBC - Survival - Pathological - Clinical.

\section{Introduction}

BREAST cancer is the most common malignant tumor among females around the world. It repre-

Correspondence to: Dr. Al-Shimaa Zakaria, The Department of Pathology, National Cancer Institute, Cairo University, Egypt sents 1.7 million new cases per year and $25 \%$ of all types of cancers, and is the second common type of cancers [1].

The incidence rate of breast cancer ranges from 19.4 per 10,000 people in East Africa to 89.7 per 100,000 in West Europe [2].

By the end of 2017, an estimated 252,710 new cases of invasive breast cancer were diagnosed among women in USA, also approximately 40,610 women died from breast cancer in 2017 [3].

In the National Cancer Institute-Cairo University (NCI-CU), breast cancer cases are representing $19.3 \%$ of total primary malignancies [4].

The most important research in the field of breast cancer was the molecular classification of breast cancer (luminal, basal-like, HER2-positive enriched and normal-like) [5]. The Triple-Negative Breast Cancer (TNBC) group representing $15 \%$ of all breast cancers, and according to (NCI-CU) cancer 12-years registry; TNBC constitutes about $13.5 \%$ of breast cancer [4] . It characterized by loss of expression of Estrogen Receptor (ER) and Progesterone Receptor (PR) and lack of over expression or amplification of the HER2/neu oncogene

TNBC often shows a more aggressive course than other molecular subtypes, with higher rates of recurrence, visceral and central nervous system metastases and poorer disease-specific survival 
We aimed to study this particular aggressive type of breast cancer in Egyptian patients diagnosed and treated in NCI regarding clinical and pathological characters, and its relation with survival and outcome.

\section{Patients and Methods}

During the time period between years 2011 and 2014, the Pathology Department at the National Cancer Institute (NCI), Cairo University, received a total number of 150 cases of triple negative breast cancer (ER, PR, and Her2neu negative). Only 59 of the collected cases could be selected regarding our inclusion criteria(cases with available blocks, available minimum follow-up of two years at time of start of study) and other cases excluded according to exclusion criteria which were (cases with lost files, unavailable blocks, incomplete follow-up data, materials with small and disfigured tumor samples).

Data were first retrieved from the information network system of the Department of Pathology at NCI. Medical files and pathology reports of all cases were retrieved and revised from both the Department of Biostatistics and Cancer Epidemiology and from the Department of Surgery, at NCI, to obtain all available data included personal data (age, gender), clinical data (date of diagnosis, date of recurrence or metastasis and treatment), pathologic data (negativity to ER, PR and Her2/neu, size of the tumor, histological type, histological grade, histological stage, lymph nodes status), and follow-up data. All included cases received the same anthracyclin based chemotherapy.

Histologic type was revised according to the criteria mentioned by World Health Organization (WHO) [2] histological grade which evaluated using the Nottingham-combined histologic grade [Elston-Ellis modification of Scarff-BloomRichardson (SBR) grading system] [8]. Staging of tumors was done according to the American Joint Committee on Cancer (AJCC) TNM staging system of breast cancer, 7 th edition [9].

\section{Statistical methods:}

Data was analyzed using IBM SPSS advanced statistics (Statistical Package for Social Sciences), Version 22 (SPSS Inc., Chicago, IL). Numerical data was described as median and interquartile range or range or mean and standard deviation as appropriate, while qualitative data were described as number and percentage. Chi-square (Fisher's exact) test was used to examine the relation between qualitative variables as appropriate.
Survival analysis was done using Kaplan-Meier method. Comparison between two survival curves was done using log rank test. Multivariate analysis was done by Cox regression model to test for independent prognostic effect of statistically significant variables on univariate level with calculating hazard ratio and its $95 \%$ confidence interval. $p$-value $\leq 0.05$ was considered significant and all test was 2 tailed. Bonferonni corrections of $p$-value was done to avoid hyperinflation of type 1 error which arises from multiple testing.

A $p$-value less than or equal to 0.05 was considered statistically significant. All tests were two tailed.

Overall Survival (OS) was calculated from date of diagnosis till date of death or last follows-up.

Disease Free Survival (PFS) was calculated from date of surgery till date of relapse, death or last follows-up.

\section{Results}

Clinical parameters: Total of 59 cases were included in the study. All the patients were females between the age group 26 to 77 years with the mean age of 48.95 years, and median age was 50 years. Most of cases are post-menopausal (52.5\%). Family history is reported in only seven cases $(11.7 \%)$. Only one case was bilateral, with rest of cases were unilateral $(98.3 \%)$. Three cases underwent recurrence and seven cases underwent metastasis, two cases show metastasis and recurrence. Forty four cases were alive, ten died, and five show lost follow-up at the end of the study (Table 1).

Pathological parameters: Infiltrating Ducal Carcinoma Not Otherwise Specified (IDC-NOS) was the only histological type. Most common grade was G2 (61\%), followed by G3 (37.3\%), and only one case is G1. Most cases represented T2 tumor size $(67.8 \%)$ followed by TI (15.3\%), T3 (10.2\%) and T4 (6.8). $62.7 \%$ of the studied cases showed positive lymph nodes, while $37.3 \%$ were negative. Only one case showed metastasis at initial presentation. Stage 2 represented $(59.3 \%)$, followed by stage $3(33.9 \%)$ stage $1(5.1 \%)$, and stage $4(1.7 \%)$ (Table 2).

\section{Survival analysis:}

The median follow-up time was 40.5 month ranging from 8 month to 67 month. At the end of the follow-up period 44 cases are alive and 10 died, and 5 lost follow-up at the end of the study. 
Overall survival and relation with clinicopathological parameters (Table 3):

Overall Survival (OS) was calculated from date of diagnosis till date of death or last follow-up, showing statistically significant relationship with stage of the tumor $(p$-value $=0.003)$ Fig. $(1 \mathrm{~A})$, grade of the tumor ( $p$-value=0.026) Fig. (1B), lymph node status ( $p$-value $=0.031)$ Fig. $(1 \mathrm{C})$, and finally with metastasis ( $p$-value <0.001) Fig. (1D). In multivariate Cox regression model, metastasis and stage were independent prognostic factors with OS.
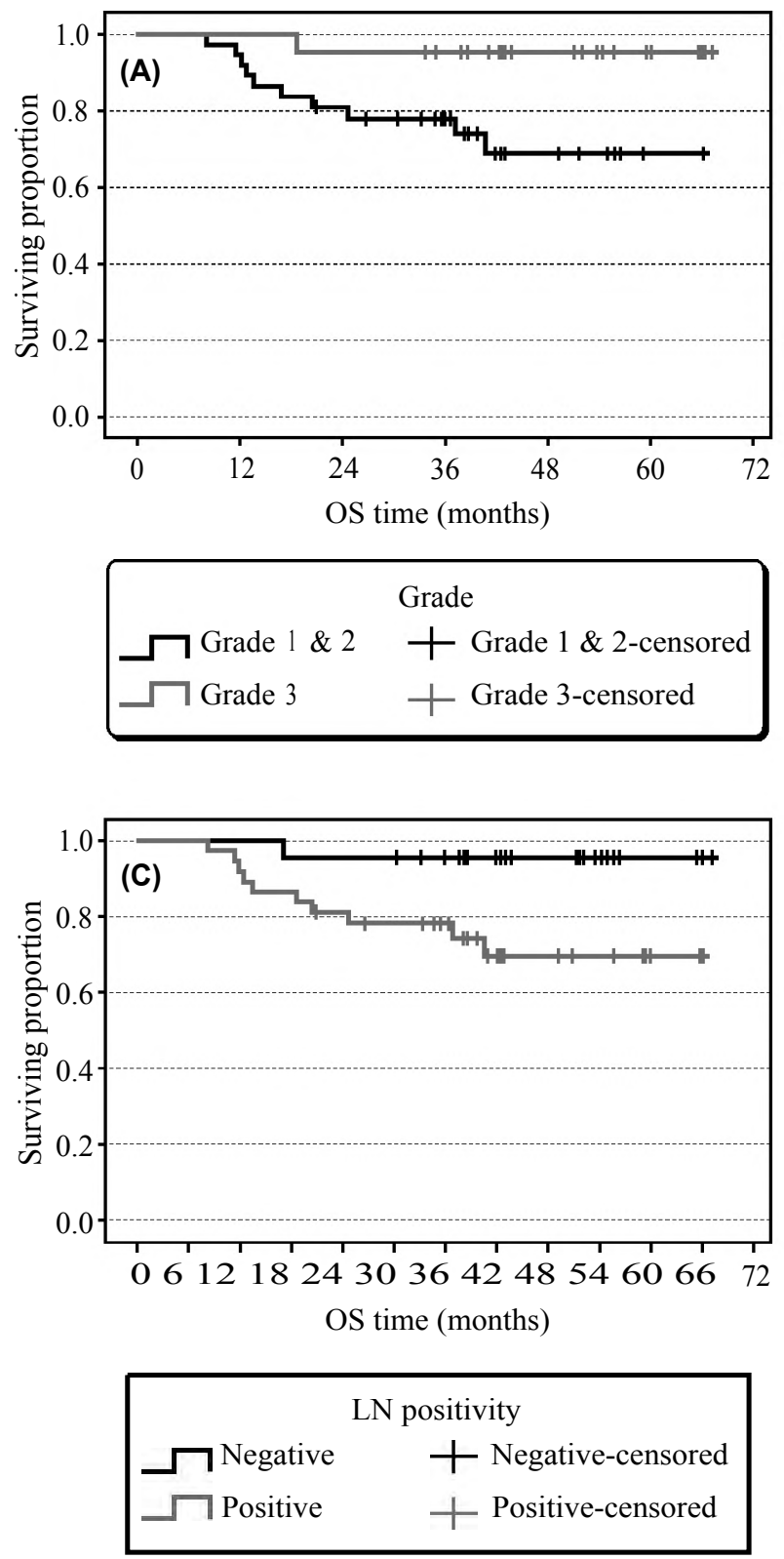

Disease free survival and relation with clinicopathological parameters (Table 4):

Disease Free Survival (DFS) was calculated from date of surgery till date of recurrence, metastasis, death or last follow-up, showing significant relationship with grade of the tumor ( $p$-value $=$ $0.035)$ Fig. (2). Late stage was associated with hazard ratio 6 times more than early stage (HR $6.366,95.0 \%$ CI 1.67-24.17, $p$-value 0.007). Also, metastasis was associated with hazard ratio 9 times more than absence of metastasis (HR 9.065, 95.0\% CI 2.73-30.05, $p$-value $<0.001)$.
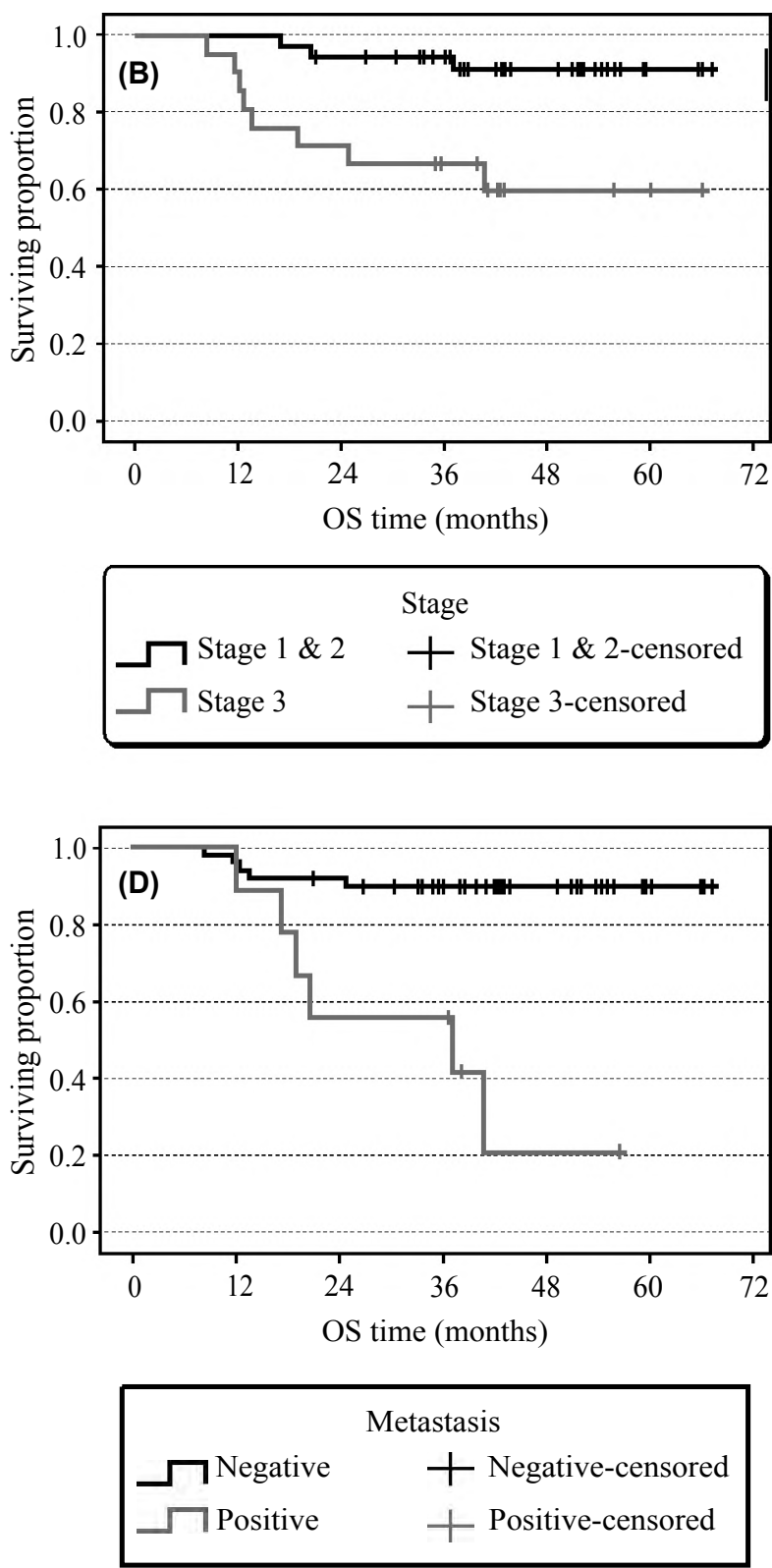

Fig. (1): (A) Overall survival time and its relation to grade ( $p$-value=002). (B) Overall survival and its relation to stage ( $p$ value $=003$ ). (C) Overall survival time and its relation to LN status ( $p$-value $<0.031)$. (D) Overall survival time and its relation to metastasis ( $p$-value $<0.001$ ). 
Table (1): Clinical parameters.

Table (2): Pathologic parameters.

\begin{tabular}{|c|c|c|c|c|}
\hline Clinical parameter & No. $(\%)$ & Pathologic parameters & & No. $(\%)$ \\
\hline $\begin{array}{c}\text { Age (years): } \\
<=50 \\
>50\end{array}$ & $\begin{array}{l}34(57.6 \%) \\
25(42.4 \%)\end{array}$ & - Grade: & $\begin{array}{l}\text { Grade I } \\
\text { Grade II } \\
\text { Grade III }\end{array}$ & $\begin{array}{l}1 \quad(1.7 \%) \\
36(61 \%) \\
22(37.3 \%)\end{array}$ \\
\hline $\begin{array}{l}\text { Menopausal status: } \\
\text { Pre } \\
\text { Post }\end{array}$ & $\begin{array}{l}28(47.5 \%) \\
31(52.5 \%)\end{array}$ & - Grade: & $\begin{array}{l}\text { Grade I \& II } \\
\text { Grade III }\end{array}$ & $\begin{array}{l}37(62.7 \%) \\
22(37.3 \%)\end{array}$ \\
\hline $\begin{array}{l}\text { Family history: } \\
\text { Positive } \\
\text { Negative }\end{array}$ & $\begin{array}{l}7(11.9 \%) \\
52(88.1 \%)\end{array}$ & - Tumor size: & $\begin{array}{l}\mathrm{T} 1 \\
\mathrm{~T} 2 \\
\mathrm{~T} 3 \\
\mathrm{~T} 4\end{array}$ & $\begin{array}{ll}9 & (15.3 \%) \\
40 & (67.8 \%) \\
6 & (10.2 \%) \\
4 & (6.8 \%)\end{array}$ \\
\hline $\begin{array}{l}\text { Laterality: } \\
\text { Unilateral } \\
\text { Bilateral }\end{array}$ & $\begin{array}{l}58(98.3 \%) \\
1 \quad(1.7 \%)\end{array}$ & - Tumor size: & $\begin{array}{l}\mathrm{T} 1 \& \mathrm{~T} 2 \\
\mathrm{~T} 3 \& \mathrm{~T} 4\end{array}$ & $\begin{array}{l}49(83.1 \%) \\
10(16.6 \%)\end{array}$ \\
\hline $\begin{array}{l}\text { Recurrence: } \\
\text { Positive } \\
\text { Negative }\end{array}$ & $\begin{array}{l}5 \\
54\end{array}$ & - Lymph nodes status: I & $\begin{array}{l}\text { Negative } \\
\text { Positive }\end{array}$ & $\begin{array}{l}22(37.3 \%) \\
37(62.7 \%)\end{array}$ \\
\hline $\begin{array}{l}\text { Metastasis: } \\
\text { Positive } \\
\text { Negative }\end{array}$ & $\begin{array}{l}9 \\
50\end{array}$ & - Positive nodes: & $\begin{array}{l}\text { N1 } \\
\text { N2 } \\
\text { N3 }\end{array}$ & $\begin{array}{l}17(45.9 \%) \\
12(32.4 \%) \\
8 \quad(21.7 \%)\end{array}$ \\
\hline $\begin{array}{l}\text { Outcome: } \\
\text { Free }\end{array}$ & 47 & $\begin{array}{l}\text { - Metastasis at initial } \mathrm{F} \\
\text { presentation: }\end{array}$ & $\begin{array}{r}\text { Present } \\
\text { Absent }\end{array}$ & $\begin{array}{ll}1 & (1.7 \%) \\
58 & (98.3 \%)\end{array}$ \\
\hline $\begin{array}{l}\text { Metastasis } \\
\text { Recurrence \& metastasis } \\
\text { Recurrence }\end{array}$ & $\begin{array}{l}7 \\
2 \\
3\end{array}$ & - Stage: & $\begin{array}{l}\text { Stage I } \\
\text { Stage II } \\
\text { Stage III }\end{array}$ & $\begin{array}{ll}3 & (5.1 \%) \\
35 & (59.3 \%) \\
20 & (33.9 \%\end{array}$ \\
\hline $\begin{array}{l}\text { Status: } \\
\text { Alive }\end{array}$ & 44 & & Stage IV & $1 \quad(.7 \%)$ \\
\hline $\begin{array}{l}\text { Died } \\
\text { Lost follow-up }\end{array}$ & 5 & - Stage: & $\begin{array}{l}\text { Stage I \& II } \\
\text { Stage III \& IV }\end{array}$ & $\begin{array}{l}38(64.4 \%) \\
21(35.6 \%)\end{array}$ \\
\hline
\end{tabular}

Table (3): Overall survival and its relation to clinicopathologic parameters and immunohistochemical marker.

\begin{tabular}{|c|c|c|c|c|c|c|}
\hline & No. & $\begin{array}{l}\text { No. of } \\
\text { events }\end{array}$ & $\begin{array}{c}\text { Cumulative survival at } \\
12 \text { months }(\%)\end{array}$ & $\begin{array}{c}\text { Cumulative survival at } \\
36 \text { months }(\%)\end{array}$ & $\begin{array}{c}\text { Cumulative survival at } \\
60 \text { months }(\%)\end{array}$ & $\begin{array}{c}p- \\
\text { value }\end{array}$ \\
\hline Whole group & 59 & 11 & $96.6 \%$ & $84.7 \%$ & $79.7 \%$ & - \\
\hline $\begin{array}{l}\text { Age: } \\
\quad \leq 50 \\
\quad>50\end{array}$ & $\begin{array}{l}34 \\
25\end{array}$ & $\begin{array}{l}4 \\
7\end{array}$ & $\begin{array}{l}97.1 \% \\
92.0 \%\end{array}$ & $\begin{array}{l}93.9 \% \\
72.0 \%\end{array}$ & $\begin{array}{l}84.9 \% \\
72.0 \%\end{array}$ & 0.089 \\
\hline $\begin{array}{l}\text { Menopausal sta } \\
\text { Pre } \\
\text { Post }\end{array}$ & $\begin{array}{l}28 \\
31\end{array}$ & $\begin{array}{l}3 \\
8\end{array}$ & $\begin{array}{l}100.0 \% \\
93.5 \%\end{array}$ & $\begin{array}{l}96.4 \% \\
74.2 \%\end{array}$ & $\begin{array}{l}85.9 \% \\
74.2 \%\end{array}$ & 0.115 \\
\hline $\begin{array}{l}\text { Family history: } \\
\text { Positive } \\
\text { Negative }\end{array}$ & $\begin{array}{l}7 \\
52\end{array}$ & $\begin{array}{l}2 \\
9\end{array}$ & $\begin{array}{l}85.7 \% \\
96.2 \%\end{array}$ & $\begin{array}{l}71.4 \% \\
86.5 \%\end{array}$ & $\begin{array}{l}71.4 \% \\
80.9 \%\end{array}$ & 0.473 \\
\hline $\begin{array}{l}\text { Grade: } \\
\text { Grade } 1 \& 2 \\
\text { Grade } 3\end{array}$ & $\begin{array}{l}37 \\
22\end{array}$ & $\begin{array}{l}10 \\
1\end{array}$ & $\begin{array}{l}94.6 \% \\
100.0 \%\end{array}$ & $\begin{array}{l}78.2 \% \\
95.5 \%\end{array}$ & $\begin{array}{l}68.8 \% \\
95.5 \%\end{array}$ & 0.026 \\
\hline $\begin{array}{l}\text { Tumor size: } \\
\text { T1 \& T2 } \\
\text { T3 \& T4 }\end{array}$ & $\begin{array}{l}49 \\
10\end{array}$ & $\begin{array}{l}7 \\
4\end{array}$ & $\begin{array}{l}95.9 \% \\
90.0 \%\end{array}$ & $\begin{array}{l}87.7 \% \\
70.0 \%\end{array}$ & $\begin{array}{l}84.8 \% \\
58.3 \%\end{array}$ & 0.070 \\
\hline $\begin{array}{l}\text { Stage: } \\
\text { Stge } 1 \& 2 \\
\text { Stge } 3 \& 4\end{array}$ & $\begin{array}{l}38 \\
21\end{array}$ & $\begin{array}{l}9 \\
8\end{array}$ & $\begin{array}{l}100.0 \% \\
90.5 \%\end{array}$ & $\begin{array}{l}94.7 \% \\
66.7 \%\end{array}$ & $\begin{array}{l}91.2 \% \\
60.0 \%\end{array}$ & 0.003 \\
\hline $\begin{array}{l}\text { LN status: } \\
\text { Positive } \\
\text { Negative }\end{array}$ & $\begin{array}{l}37 \\
22\end{array}$ & $\begin{array}{l}10 \\
1\end{array}$ & $\begin{array}{l}94.6 \% \\
100.0 \%\end{array}$ & $\begin{array}{l}78.2 \% \\
95.5 \%\end{array}$ & $\begin{array}{l}69.6 \% \\
95.5 \%\end{array}$ & 0.031 \\
\hline $\begin{array}{c}\text { Metastasis: } \\
\text { Positive } \\
\text { Negative }\end{array}$ & $\begin{array}{l}9 \\
50\end{array}$ & $\begin{array}{l}6 \\
5\end{array}$ & $\begin{array}{l}100.0 \% \\
96.0 \%\end{array}$ & $\begin{array}{l}55.6 \% \\
89.9 \%\end{array}$ & $\begin{array}{l}\mathrm{NR} \\
89.9 \%\end{array}$ & $<0.001$ \\
\hline
\end{tabular}

NR: Not Reached. 
Table (4): Disease free survival and its relation to clinicopathologic parameters and immunohistochemical markers.

\begin{tabular}{|c|c|c|c|c|c|c|c|}
\hline & No. & $\begin{array}{l}\text { No. of } \\
\text { events }\end{array}$ & $\begin{array}{c}\text { Cumulative } \\
\text { survival at } \\
12 \text { months (\%) }\end{array}$ & $\begin{array}{c}\text { Cumulative } \\
\text { survival at } \\
36 \text { months (\%) }\end{array}$ & $\begin{array}{c}\text { Cumulative } \\
\text { survival at } \\
60 \text { months }(\%)\end{array}$ & $\begin{array}{l}\text { Median } \\
\text { survival } \\
\text { estimate }\end{array}$ & $\begin{array}{c}p- \\
\text { value }\end{array}$ \\
\hline Whole group & 59 & 20 & $100 \%$ & $92.5 \%$ & $67.9 \%$ & 67.900 & - \\
\hline $\begin{array}{l}\text { Age: } \\
\quad<50 \\
\quad>50\end{array}$ & $\begin{array}{l}34 \\
25\end{array}$ & $\begin{array}{l}10 \\
10\end{array}$ & $\begin{array}{l}100 \% \\
100 \%\end{array}$ & $\begin{array}{l}93.8 \% \\
95.7 \%\end{array}$ & $\begin{array}{l}82.0 \% \\
53.8 \%\end{array}$ & $\begin{array}{l}67.900 \\
76.900\end{array}$ & 0.922 \\
\hline $\begin{array}{l}\text { Menopausal stat } \\
\text { Pre } \\
\text { Post }\end{array}$ & $\begin{array}{l}28 \\
31\end{array}$ & $\begin{array}{l}9 \\
11\end{array}$ & $\begin{array}{l}100 \% \\
100 \%\end{array}$ & $\begin{array}{l}96.2 \% \\
89.3 \%\end{array}$ & $\begin{array}{l}75.4 \% \\
61.4 \%\end{array}$ & $\begin{array}{l}66.900 \\
76.900\end{array}$ & 0.764 \\
\hline $\begin{array}{l}\text { Family history: } \\
\text { Positive } \\
\text { Negative }\end{array}$ & $\begin{array}{l}7 \\
52\end{array}$ & $\begin{array}{l}4 \\
16\end{array}$ & $\begin{array}{l}100 \% \\
100 \%\end{array}$ & $\begin{array}{l}100 \% \\
91.3 \%\end{array}$ & $\begin{array}{l}75.5 \% \\
67.0 \%\end{array}$ & $\begin{array}{l}64.900 \\
72.900\end{array}$ & 0.757 \\
\hline $\begin{array}{l}\text { Grade: } \\
\quad \text { Grade } 1 \& 2 \\
\text { Grade } 3\end{array}$ & $\begin{array}{l}37 \\
22\end{array}$ & $\begin{array}{l}17 \\
3\end{array}$ & $\begin{array}{l}100 \% \\
100 \%\end{array}$ & $\begin{array}{l}88.4 \% \\
100 \%\end{array}$ & $\begin{array}{l}60.5 \% \\
85.7 \%\end{array}$ & $\begin{array}{l}66.900 \\
77.900\end{array}$ & 0.035 \\
\hline $\begin{array}{l}\text { Tumor size: } \\
\text { T1 \& T2 } \\
\text { T3 \& T4 }\end{array}$ & $\begin{array}{l}49 \\
10\end{array}$ & $\begin{array}{l}15 \\
5\end{array}$ & $\begin{array}{l}100 \% \\
100 \%\end{array}$ & $\begin{array}{l}90.9 \% \\
100 \%\end{array}$ & $\begin{array}{l}67.2 \% \\
71.4 \%\end{array}$ & $\begin{array}{l}66.900 \\
75.900\end{array}$ & 0.173 \\
\hline $\begin{array}{l}\text { Stage: } \\
\text { Stge } 1 \& 2 \\
\text { Stge } 3 \& 4\end{array}$ & $\begin{array}{l}38 \\
21\end{array}$ & $\begin{array}{l}11 \\
9\end{array}$ & $\begin{array}{l}97.4 \% \\
100 \%\end{array}$ & $\begin{array}{l}94.6 \% \\
89.5 \%\end{array}$ & $\begin{array}{l}69.3 \% \\
66.1 \%\end{array}$ & $\begin{array}{l}66.900 \\
75.900\end{array}$ & 0.852 \\
\hline $\begin{array}{l}\text { LN status: } \\
\text { Positive } \\
\text { Negative }\end{array}$ & $\begin{array}{l}37 \\
22\end{array}$ & $\begin{array}{l}17 \\
3\end{array}$ & $\begin{array}{l}100 \% \\
100 \%\end{array}$ & $\begin{array}{l}91.1 \% \\
95.5 \%\end{array}$ & $\begin{array}{l}65.6 \% \\
27.7 \%\end{array}$ & 66.900 & 0.276 \\
\hline
\end{tabular}

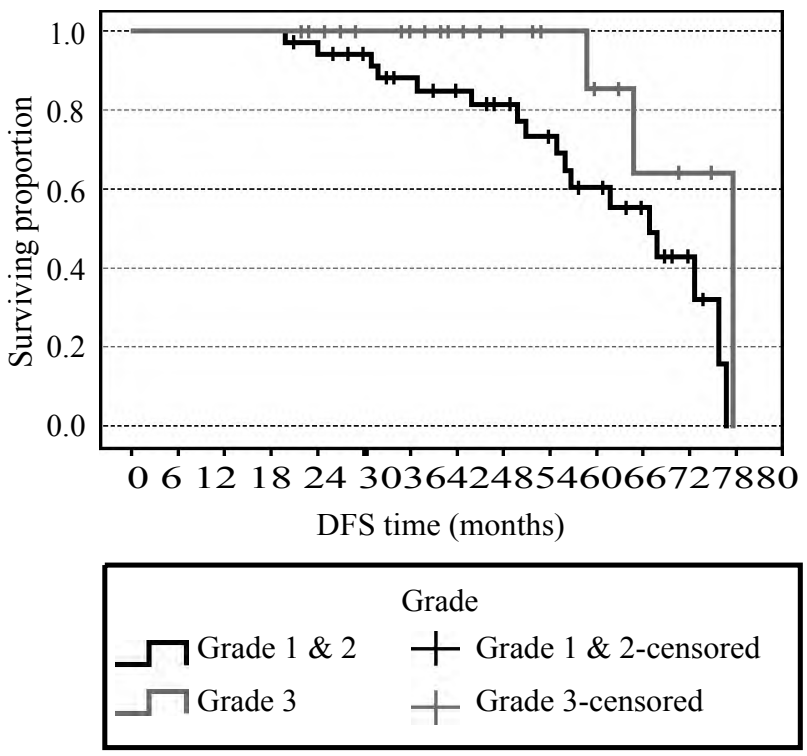

Fig. (2): Disease free survival time and its relation to grade $(p$-value $=0.035)$.

\section{Discussion}

In our study the mean age of the studied group is 48.95 years , and median is 50 years, with most cases $<$ or $=50$ years represented $57.6 \%$, similar to what reported by many studies with the mean age of the TNBC group was 46.26 and 45 years old $[10,11]$.
Low overall breast cancer incidence rates in young age are related to the healthy estrogen surveillance in the many of young women, so that in young cases, tumor may develop as a consequence of strong risk factor associated with breast cancer, as positive family history, BRCA gene mutation, irregular cycles which diminish the estrogen synthesis causing damage of the estrogen signaling in young cases, leading to occurrence of TNBC in younger age group [12]

Most of cases are post-menopausal (52.5\%) similar finding was reported by Pistelli and colleagues with the majority of cases $(55.7 \%)$ had a post-menopausal status [13]. This could be explained by decrease of estrogen in this period of age, leading to development of tumor in most of the postmenopausal cases were around fifty years old which was the mean age in this study. Also, another contributing factor which was lack of use of hormone replacement therapy in this group of patients, especially in developing countries, which offer good protective method that balance the estrogen deficiency.

Only seven cases in our study have positive family history of breast cancer, while the majority of cases showed negative family history, which is observed in Anderson and colleagues study with 
non-significant associations between family history and TNBC [14], contrary to many other studies which worked on large scale of cases $[15,16]$.

Most of cases of our study represent T2 stage (67.8\%), followed by T1 (15.3\%), T3 (10.2\%) and T4 $(6.8 \%)$, stage II represents majority of cases $(59.3 \%)$ followed by stage III (33.9\%), and stage $1(5.1 \%)$, grade II represents $(61 \%)$, grade III $(37.3 \%)$, and only one case belongs to grade I. High incidence of node positivity (62.7\%) is noted. This is similar to what was observed by some studies with higher ratio of tumors with $\mathrm{T} 2$ and high grade [13]. Also as Zhang and colleagues who noticed high percentage of node positivity among the studied cases [17].

Recurrence together with metastasis are observed in $21 \%$ of cases, illustrated that the disease course for patients diagnosed with TNBC often follows a more aggressive course, with higher rates of early recurrence and metastases as what was documented by some studies [7].

All studied cases are carcinoma of no special type (IDC-NOS), which did not differ from Preethi study in which infiltrating ductal carcinoma of no special type (IDC-NOS) was the predominant histological type [18].

The disease course for patients in our study revealed significant relationship between the disease free and overall survival and grade of the tumor, $p$-value: 0.035 and 0.026 respectively. An interesting finding is that high grades recorded better DES and OS than the lower grade ones, which could be attributed to better responsiveness to the chemotherapy among patients with tumors of high grades, as reported by Pinder and colleagues who observed that patients with high grade breast carcinomas may benefit from prolonged, rather than pre-operative chemotherapy [19], while, higher stage, occurrence of metastasis and node positivity were significantly related to lower overall survival, reflecting the strong impact of the standard prognostic factors in breast cancer among the triple negative molecular subtype.

We concluded that triple negative breast cancer group is an aggressive subtype were more noticed among age group less than 50 years, which express pathologically high grade, large tumor size, high stage and node positivity. Significant relationship was found between grade and DFS, as well as OS with grade, stage, occurrence of metastasis and node positivity.

\section{References}

1- FERLAY J., SOERJOMATARAM I., DIKSHIT R., ESER S., MATHERS C., REBELO M., et al.: Cancer incidence and mortality worldwide: sources, methods and major patterns in Globocan 2012. International Journal of Cancer, 136 (5), 2015.

2- LAKHANI S.R., ELLIS I.O., SCHNITT S.J., TAN P.H. and VAN De VIJVER M.J.: Tumors of the breast In World Health Organization Classification of Tumors. Pathology and Genetics of tumors of breast and female genital organs, 4th edition, P8. IARC Press: Lyon, 2012.

3- SIEGEL L., MILLER D. and JEMAL A.: Cancer statistics. CA Cancer J., 67: 7-30, 2017.

4- MOHAMED G.: Breast cancer In: Mokhtar, N., Salama, A., Badawy, O., Khorshed, E., Abdelazim, H.: Cancer pathology registry 2000-2011; chapter 2, pp. 8-31, 2016.

5- PEROU C.M., SØRLIE T., EISEN M.B., VAN De RIJN M., JEFFREY S.S., REES C.A., et al.: Molecular portraits of human breast tumours. Nature, 406 (6797): 747-52, 2000.

6- NIELSEN T.O., HSU F.D., JENSEN K., CHEANG M., KARACA G., HU Z., et al.: Immunohistochemical and clinical characterization of the basal-like subtype of invasive breast carcinoma. Clinical Cancer Research, 10 (16): 5367-74, 2004.

7- DENT R., HANNA W.M., TRUDEAU M., RAWLINSON E., SUN P. and NAROD S.A.: Pattern of metastatic spread in triple-negative breast cancer. Breast Cancer Research and Treatment, 115 (2): 423-8, 2009.

8- EASTON D.F.: Familial risks of breast cancer. Breast Cancer Research, 4 (5): 179, 2002.

9- EDGE S.B. and COMPTON C.C.: The American Joint Committee on Cancer: The $7^{\text {th }}$ edition of the AJCC cancer staging manual and the future of TNM. Annals of surgical oncology, 17 (6): 1471-14774, 2010.

10- SAJID, M.T., AHMED M., AZHAR M., MUSTAFA Q., SHUKR I. and KAMAL Z.: Age-related frequency of triple negative breast cancer in women. J. Coll Physicians Surg. Pak., 24 (6): 400-3, 2014.

11- BAUER K.R., BROWN M., CRESS R.D., PARISE C.A. and CAGGIANO V.: Descriptive analysis of Estrogen Receptor (ER) negative, Progesterone Receptor (PR) negative, and HER2 negative invasive breast cancer, the so_called triple negative phenotype. Cancer, 109 (9): $1721-8,2007$.

12- SUBA Z.: Triple-negative breast cancer risk in women is defined by the defect of estrogen signaling: Preventive and therapeutic implications. OncoTargets and therapy, 7: 147-64, 2014.

13- PISTELLI M., PAGLIACCI A., BATTELLI N., SANTINELLI A., BISCOTTI T., BALLATORE Z., et al.: Prognostic factors in early-stage triple-negative breast cancer: Lessons and limits from clinical practice. Anticancer research, 33 (6): 2737-42, 2014.

14- ANDERSON K., THOMPSON P.A., WERTHEIM B.C., MARTIN L., KOMENAKA I.K., BONDY M., et al.: Family history of breast and ovarian cancer and triple negative subtype in hispanic/latina women. Springerplus, 3 (1): 727, 2014. 
15- ROBERTSON L., HANSON H., SEAL S., WARRENPERRY M., HUGHES D., HOWELL I., et al.: BRCA1 testing should be offered to individuals with triple-negative breast cancer diagnosed below 50 years. British Journal of Cancer, 106 (6): 1234, 2012.

16- GREENUP R., BUCHANAN A., LORIZIO W., RHOADS K., CHAN S., LEEDOM T., et al.: Prevalence of BRCA mutations among women with triple-negative breast cancer (TNBC) in a genetic counseling cohort. Annals of Surgical Oncology, 20 (10): 3254-8, 2013.

17- ZHANG L., HAO C., DONG G. and TONG Z.: Analysis of clinical features and outcome of 356 triple-negative breast cancer patients in China. Breast Care, 7 (1): 13-7, 2012.

18- PREETHI S., AIL D.A. and PRAKASH G.: Study of CK5/6 expression in invasive breast carcinomas and its utility as an independent prognostic marker. Global Journal for Research Analysis, 6 (1): 99-102, 2017.

19- PINDER S.E., MURRAY S., ELLIS I.O., TRIHIA H., ELSTON C.W., GELBER R.D., et al.: The importance of the histologic grade of invasive breast carcinoma and response to chemotherapy. Cancer, 83 (8): 1529-39, 1998.

\title{
دراسة إكلينيكية وباثولوجية

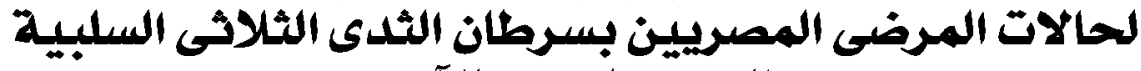

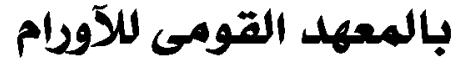

\author{
تعتبر مجموعة سرطان الثدى ثلاثى السلبية من آهم مجموعات سرطان الثدى التى تحتاج دراسة تقصيلية. \\ الهدف من الدراسةد: دراسة الخصائص الإكلينيكية والباثولوجية للمرضى المصريين بسرطان الثى ثلاثى السلبية. \\ طرق البحث: آجريت الدراسة على عدد 9 ه سيدة مصابين بسرطان الثدى ثلاثى السلبية، تم تشخيصهم فى قسم الباثولوجى بالمعهد

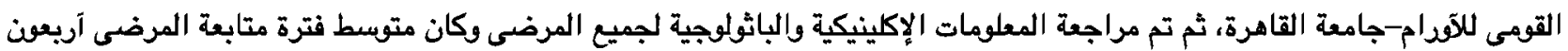

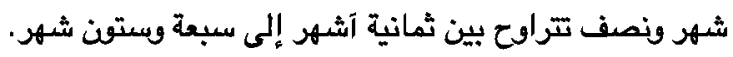

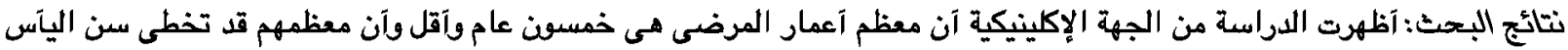

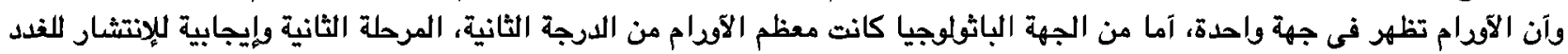

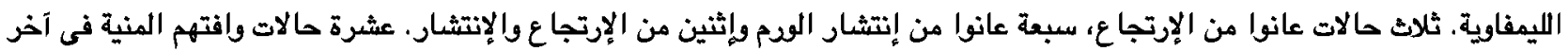

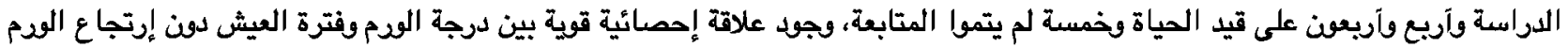

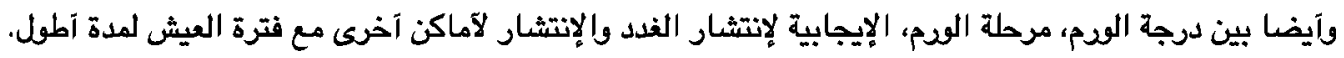

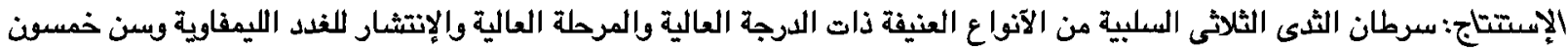

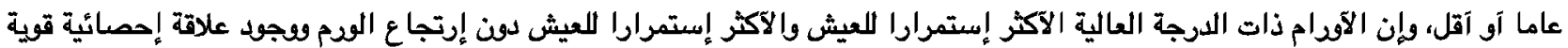

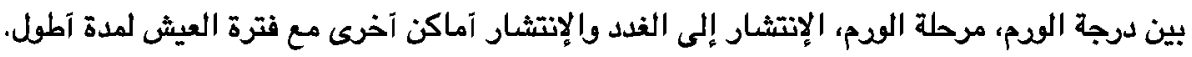

